\title{
Urgences
}

\section{Le funambule (extrait de " Ires funambulesques ")}

\section{Ghislain Bérubé}

Numéro 4, 2e trimestre 1982

URI : https://id.erudit.org/iderudit/025061ar

DOI : https://doi.org/10.7202/025061ar

Aller au sommaire du numéro

Éditeur(s)

Urgences

ISSN

0226-9554 (imprimé)

1927-3924 (numérique)

Découvrir la revue

Citer ce document

Bérubé, G. (1982). Le funambule (extrait de " Ires funambulesques "). Urgences, (4), 59-62. https://doi.org/10.7202/025061ar d'utilisation que vous pouvez consulter en ligne.

https://apropos.erudit.org/fr/usagers/politique-dutilisation/ 
GHISLAIN BÉRUBÉ

\section{Le funambule}

(Extrait de "Ires funambulesques") 
il court il marche

un passé dans ses cheveux fous

ivres comme la dernière marée

ce vieux funambule du désir

il court il marche

un désir dans des yeux sombres

maganés par I'hallucination

ce vieux funambule du risque

il court il marche

une amitié au coeur

une parole au bout des lèvres

une dernière blague dans la gorge

ce vieux funambule de la farce

comme toujours comme avant

il marche sur cette corde asphaltée de l'espoir

ses spectateurs déguisés en buildings gifflent le soleil

il marche en équilibre

évite tous ces manèges dont le conducteur use du klaxon seul porte-parole d'un automatisme délirant

fil barbelé de l'aliénation mécanique banale 
seul en équilibre

sur des rues plus grandes que sa déception

ce vieux musicien de l'hôtel du coin

se refait l'oeil en lorgnant de jeunes printemps

ces effeuilleuses rajeunies

il ralentit

chaque rue traversée chaque building dépassé

chaque regard triste EST UN PAS VERS LA MORT

il crie à ceux qui veulent l'entendre

" $j$ 'aime encore toucher la sensuelle coutume d'aimer

j'aime encore la crise cardiaque d'amour

qui te garroche dans les bras de celle qui

la veille te faisait pleurer

j'aime encore sourire aux yeux flamboyants du désir"

on se rassemble autour de lui

un flic lui dit de se taire

une vieille dame lui redonne son accordéon

il joue sur le mail entouré de gens qu'il aime

l'accordéon devient une tempête

bourrasque qui émet les plus beaux vents du coeur

devient douceur

frôle la cuisse de la sensibilité

se transforme doucement

en une feuille d'automne qui boit

le givre réchauffé 
le vieil homme se retire de la mort pour la vie

l'accordéon de ce vieux musicien funambule respire les derniers printemps

de celui qui le tenait si bien témoigne des fiançailles de ceux qui empoignent encore le lys et la rose comme pour serrer de plus près les derniers instants d'une vie achevée

la musique-parole de ce vieux musicien tombe sur cette rue corde pour un funambule se promène en coup de vent pour un équilibre suicidé 